\title{
Research Paper Marketing and price spread of tomato in Western Vidarbha region of Maharashtra
}

See end of the paper for authors' affiliations

Correspondence to :

S. D. Wankhade

Department of Agricultural Economics and Statistics, Dr. Panjabrao Deshmukh Krishi Vidyapeeth, Akola (M.S.) India

Paper History :

Received : 02.11.2018,

Revised : 11.02.2019;

Accepted : 21.02.2019
ABSTRACT : The study on marketing of tomato in Western Vidarbha region of Maharashtra i.e. in Akola, Washim, Buldhana, Yawatmal and Amravati. Data pertained to the year 2010-11 and 2011-12. For the study, two tehsil of each district and from each tehsil two markets selected and from each market five wholesaler and five retailer were selected. Hence, 50 wholesaler and 50 retailer were purposively selected. Data was collected according to specially designed questionnaire prepared for study of marketing. There were three marketing channels i.e. Produce $\rightarrow$ Consumer, Producer $\rightarrow$ Wholesaler $\rightarrow$ Consumer, Producer $\rightarrow$ Wholesaler $\rightarrow$ Retailer $\rightarrow$ Consumer were selected. The results revealed thatthe total cost incurred by producer out of the total cost of marketing of tomato was Rs. 85.40/- In channel - I and it increases channel wise i.e. Rs. 144.70/- in channel - II, and Rs. 250.87/- in channel - III. Producers share in consumers rupee in channel - III was 44.20 per cent in channel - II was 67.11 per cent and in channel - I was 88.17 per cent. It showed that if share of various intermediaries decreases the producers share in consumers rupee increases.

KEY WORDS : Tomato, Marketing, Price spread

How To Cite This PAPer : Wankhade, S.D., Kakde, S.J., Kolhe, R.K. and Deshmukh, R.G. (2019). Marketing and price spread of tomato in Western Vidarbha region of Maharashtra. Internat. Res. J. Agric. Eco. \& Stat., 10 (1) : 139-142, DOI : 10.15740/HAS/IRJAES/10.1/139-142. Copyright@ 2019: Hind Agri-Horticultural Society. 